\title{
Effect of tannins on nitrogen balance and microbial activity of rumen fluid in sheep and goats
}

\author{
H. NARJISSE *, M. EL HANSALI ** \\ * National School of Agriculture, Meknes, Morocco \\ $*$ National Institute of Agronomy and Veterinary medecine, Rabat, Morocco
}

\begin{abstract}
Oak leaves (Quercus rotundifolia), an important forage resource in Morocco, significantly contribute to domestic livestock feeding especially after the growing season when the herbaceous vegetation becomes scarce. Unfortunately, the high content of this forage is suspected to limit the grazing animal performances. This study was designed to investigate the effect of tannins on the nitrogen balance in sheep and goats and on potentially related parameters such as plasma urea nitrogen (PUN) and rumen ammonia nitrogen. Additionally, the potential influences of increasing tannin concentrations on the fermentation capacity of sheep and goat rumen fluid were also investigated.

Results indicate that the infusion of 36 and $18 \mathrm{~g}$ of tannins into the rumen of four sheep and four goats fed approximately equal quantities of low quality hay, depressed the nitrogen balance in sheep $(13.58 \mathrm{mg} \mathrm{N} / \mathrm{kg} \mathrm{LW}$. in control animals versus - $8.06 \mathrm{mg} \mathrm{N}$ fixed $/ \mathrm{kg}$ of liveweight in experimental animals), while it improved it in goats $(85.14 \mathrm{mg} \mathrm{N} / \mathrm{kg} \mathrm{LW}$. versus $123 \mathrm{mg} \mathrm{N} / \mathrm{kg}$ of live weight).

However, infusion of tannin solutions similarly affected the plasma urea nitrogen concentration in sheep and goats. PUN decreased from 11.23 to $8.95 \mathrm{mg} / 100 \mathrm{ml}$ and from 42.52 to $22.46 \mathrm{mg} / 100 \mathrm{ml}$ respectively in sheep and goats. A similar pattern was also noted for rumen ammonia nitrogen which decreased in both animal species following tannin infusion.

On the other hand, the data obtained in an «in vitro » study indicate that the fermentation capacity of sheep rumen fluid tends to be inhibited by increasing amounts of tannins. On the contrary, an increase in the tannin concenration stimulates the rumen fluid fermentation capacity in goats.

Thus, incubation of rumen fluid with 12 p. 100 tannin concentration (on the dry matter basis of the substrate depressed the fermentation capacity of sheep rumen fluid by five points and improved that of goats by the same amount).

According to these results, which are in line with those obtained in a feeding behaviour study, it may be concluded that goats seem to tolerate tannins much better than sheep do. Further investigations are required to elucidate the mechanism of this tolerance.
\end{abstract}

Key words : Tannins, nitrogen balance, rumen, sheep, goat, urea.

\section{Influence of roughage quality on feed intake, milk production and nutrient utilization in the lactating Saanen goat}

\section{J. KESSLER}

\author{
Swiss Federal Research Station for Animal Production \\ Grangeneuve, $\mathrm{CH}-1725$ Posieux
}

The influence of two hay diets of different quality on feed intake, milk production and nutricnt utilization was studied in 12 lactating Saanen goats in a balance trial (beginning of the 1st adaptation period : 6 weeks after parturition). The experiment which was carried out as 
a cross-over design consisted of two 21-day adaptation periods followed by a $2 \times 4$-day balance period with faeces- and urine-sampling. The nutrient- and mineral content in the dry matter of the bald quality hay (A) was : 86.3 p. 100 organic matter (OM), 31.5 p. 100 crude fibre (CF), 12.3 p. 100 crude protein (CP), 0.51 p. $100 \mathrm{Ca}, 0.35$ p. 100 P, 0.16 p. $100 \mathrm{Mg}$, 2.58 p. $100 \mathrm{~K}, 0.03$ p. $100 \mathrm{Na}$ and $4.69 \mathrm{MJ} / \mathrm{kg}$ net energy lactation (NEL) that of the good quality hay (B) was : 89.4 p. $100 \mathrm{OM}, 25.7$ p. $100 \mathrm{CF}, 14.6$ p. $100 \mathrm{CP}, 0.70$ p. $100 \mathrm{Ca}$, 0.36 p. $100 \mathrm{P}, 0.18$ p. $100 \mathrm{Mg}, 3.05$ p. $100 \mathrm{~K}, 0.03$ p. $100 \mathrm{Na}$ and $5.45 \mathrm{MJ} / \mathrm{kg} \mathrm{NEL}$.

Feeding of the bad quality hay led - compared to the good quality - one to a significantly $(\mathrm{P}<5$ p. 100$)$ reduced level of feed intake $(\mathrm{A}: 1.1 \mathrm{~kg} \mathrm{DM} /$ day $; \mathrm{B}: 1.9 \mathrm{~kg} \mathrm{DM} /$ day $)$ followed by a striking decline in the milk production (A: $1.0 \mathrm{~kg} /$ day; $\mathrm{B}: 1.9 \mathrm{~kg} / \mathrm{day}$ ). Furthermore, digestibility of OM (A : 63.9 p. $100: \mathrm{B}: 70.2$ p. 100) and of CF (A : 68.3 p. $100 ; B: 71.2$ p. 100$)$ was significantly lower. No significant difference could be observed in CP (A: 63.7 p. 100 ; B : 64.6 p. 100).

Owing to homeostatic regulation mechanisms the animals which received diet $A$ were - in spite of the inadequate Ca- and P-supply - able to balance their $\mathrm{Ca}$ - and P-metabolism to a large extent. The daily Ca-turnover in $\mathrm{g}$ in groups $\mathrm{A}$ and $\mathrm{B}$ was respectively : intake $4.75,12.79$; faeces $3.80,11.13$; urine $0.01,0.08$; milk $1.17,2.03$ and retention - 0.24 resp. -0.47 . The corresponding figures for the P-turnover were intake 3.94, 6.95; faeces $2.32,4.83$; urine $0.48,0.10$; milk $0.90,1.48$ and retention 0.25 resp. 0.54 . In p. 100 of the intake there was a significant difference between the two groups for the urine Ca-excretion as well as for the faeces- and urine P-excretion.

The large $\mathrm{K}: \mathrm{Na}$ ratio of diet $\mathrm{B}(30: 1)$ did not lead to the partly described excessive Na-excretion in the urine. On the other hand a depressive influence of the relatively high K-supply on the Mg-digestibility was observed (A : 36.0 p. 100, B : 29.0 p. 100, P $<5$ p. 100).

Neither the relatively narrow correlation (as it is described by some authors) between the crude fibre content of the diet and the mineral utilization nor the positive influence of the crude protein content of the diet on the Ca-retention could be observed in this experiment. This partly results from the relatively small differences in the CF- and CP-content of the diet. The correlation between energy supply and P-retention was also only low ( $r=0.43$ ).

Key words : Roughage, quality, intake, nutrient, mineral utilization, goat.

\title{
Weight and metabolism of goat adipose tissues during pregnancy and lactation
}

\section{P. BAS *, P. MORAND-FEHR *, Annie ROUZEAU *, Y. CHILLIARD **}

\author{
*Station de Nutrition et Alimentation (I.N.R.A.) \\ Institut National Agronomique Paris-Grignon \\ 16, rue Claude-Bernard, 75231 Paris Cedex 05 (France) \\ $*$ Laboratoire des Productions Laitières (I.N.R.A.) \\ Theix, 63122 Ceyrat (France)
}

Variations in adipose tissue weight and metabolism during the reproductive cycle of goats were studied as the information in this field was scarce in high milk yielding ruminants.

Thirty one, 3-8 year old Alpine goats were slaughtered at five stages of the reproductive cycle : at $7(\mathrm{~W}-7)$ or 3 weeks $(\mathrm{W}-3)$ before parturition or respectively at 2 $(\mathrm{W}-2), 4(\mathrm{~W}+4)$ and between $36-39(\mathrm{~W}-36)$ weeks after kidding.

Maternal empty body weights were $50.7,51.2,47.0,47.9,47.8 \mathrm{~kg}$ with a coefficient of variation (C.V.) $23.4,18.8,9.1,13.0,9.5$ p. 100 respectively for animals slaughtered at $-7,-3,+2,+4,+36 \mathrm{~W}$. 